\title{
IMPACT OF Allium sativum AGAINST Enterobacter sp. AS WATER BORNE PATHGENIC BACTERIA ISOLATED FROM RIVER NILE
}

\section{Rasha A. Ebrahim ${ }^{1,{ }^{\star}}$, Rawia F. Gamal' ${ }^{2}$, Samah H.A. Mohamed ${ }^{2}$ and Abdel-Rahman ${ }^{3}$ R.Z.}

1- Medical Analysis Central Laboratories for Medical Analysis and Blood Bank of Armed Forces, Al-Khalifa Al-Ma'mun, Cairo, Egypt

2- Agric. Microbiology Dept., Fac. of Agric., Ain Shams Univ., P.O. Box 68, Hadayek Shobra 11241, Cairo, Egypt

3- Medical Microbiology Dept., Military Medical Academy, Al-Khalifa Al-Mamun, Cairo, Egypt

*Corresponding author: Eman_es2007@yahoo.com

Received 2 August 2018

Accepted 29 August, 2018

\section{ABSTRACT}

To explore the antibacterial activities of Allium sativium (garlic) extract was tested against two waterborne pathogenic strains isolated from River Nile, to mitigate the increase of bacterial resistance to conventional antibiotics. The two isolates were identified as Enterobacter cloacae DSM 3264 BRB \& Enterobacter cloacae MB11506_1CHB by MALDI-Tof-MS. Aqueous, methanolic and oil extraction of garlic were tested for their inhibitory activity against the selected strains using well diffusion method. Enterobacter sp. were more sensitive towards oil extract with inhibition zone $2.3 \mathrm{~cm}$ rather than aqueous and methanolic extractions with was $50 \%$. Analysis of garlic essential oil by GC-MS dedicated six sulfur compounds represented $25 \%$ of total detected compounds in the oil.

Keywords: Enterobacter cloacae, Garlic oil, MALDI-Tof-MS, GC-MS spectrometry. Allium sativum, Well diffusion method

\section{INTRODUCTION}

Garlic plant (Allium sativum) is mainly classified as a species member of the family Alliaceae (onions), subfamily Allioideae, and the Allium genus. Garlic plant has many biological activities such as anti-fungal, anti-septic and antihistamine. It has been used as traditional remedy for cold, cough and asthma treatment (Gebreselema and Gebreyohannes 2013). As described by (Palani et al 2014), Allium sativum has a chemical composition of many components; sulfur compounds: allicin, alliin, allylpropyl disulfide, diallyl trisulfide (DATS), S-allylmercaptocysteine, S-allylcysteine (SAC), several enzymes, such as (allinase, myrosinase, catalases, superoxide dismutases, arginases and lipases), amino acids (arginine, glutamic acid, aspartic acid, methionine and threonine), proteins (glutamyl peptides), vitamins (B1, B2, B6, C, Biotin and nicotinic acid), minerals (Selenium, Germanium, Tellurium and other trace minerals), elements, lipids, prostaglandins, fructan, pectin and adenosine.

Early Egyptians used garlic to treat diarrhea and its medical power was drawn on the walls of ancient temples and on papyrus dating to $1500 \mathrm{BC}$ (Gebreselema and Gebreyohannes 2013). The Old Greeks, Hippocrates and Galen Garlic tried garlic to cure intestinal and extra-intestinal disease infections. Ancient Chinese and Japanese used it as headache, flu, sore throat and fever remedies. In Africa, especially in Nigeria, garlic is traditionally used to heal the abdominal infections, diarrhea and respiratory tract infections [Jaber and Al-Mossawi, 2007 and Gebreselema and Gebreyohannes, 2013]. European and Indian people used it in folk remedies to recover high fever, asthma and common colds. Garlic has a byname as Russian penicillin due tops its large scale utilities as intrinsic antimicrobial agent; it is commonly used in many cultures as an excitement and reputation of healing power (Timbo et al 2006). As noted by Palani et al (2014) garlic oil extracts had a high antibacterial potential against 
both of Gram positive and Gram negative bacteria as well as species of Escherichia, Klebsiella, Salmonella, Proteus, Staphylococcus, Streptococcus, Bacillus, and Clostridium. According to Cellini et al (1996) and Palani et al (2014), aqueous garlic extract at concentrations of $2-5 \mathrm{mg} / \mathrm{ml}$ inhibited the growth of Helicobacter pylori clinical isolates from patients suffered from chronic gastritis or duodenal ulcer. Rubin et al (2012), reported that $0.1 \mathrm{ml}$ of $10 \%(\mathrm{w} / \mathrm{v})$ extract of garlic inhibited the growth of Staphylococcus aureus with diameter zone of inhibition ranged from $19.68-20.75 \mathrm{~mm}$ with mean of $20.22 \mathrm{~mm}$ diameter of inhibition zone. Jan et al (2014) showed that the mode of action of garlic oils is reverted to the existence of allicin which causes a total inhibition of RNA and DNA synthesis. While Brij et al (2016) found that thiosulfinates and other, glutamyl peptides, Scordinins, Steroids, terpenoids, flavonoids and other phenols, have the most inhibitory effect on protein synthesis.

\section{MATERIALS AND METHODS}

Microorganisms: Two isolates were isolated from River Nile in Egypt namely Enterobacter sp. (19) and Enterobacter sp. (37) in a previous work. Media used: all medium components were prepared as decribed by (APHA, 1992) MacConkey agar No.3 (g/l) peptone 20.0 , lactose 10.0 , bile salts, sodium chloride 5.0 , neutral red 0.03 , crystal violet 0.001 , agar 15.0 with $\mathrm{pH}$ adjusted to $7.1 \pm$ 0.2 at $25^{\circ} \mathrm{C}$. It is used for Enterobacter sp. Nutrient agar medium $(\mathrm{g} / \mathrm{l})$ with composition of meat extract 3, peptone 5, $\mathrm{pH} 7$. Tryptone glucose yeast extract broth (TGY) ( $\mathrm{g} / \mathrm{l})$ Casein enzymic hydrolysate 10.0 , yeast extract 1.0 , glucose 5 , dipotassium phosphate 1.25. It was used for the maintenance of the isolate. Muller and Hinton agar (g/l) beef, dehydrated infusion 30.0, casein hydrolysate 17 , Starch 1.5, agar 17.0 with $\mathrm{pH}$ adjusted to $7.3 \pm 0.1$ at $25^{\circ} \mathrm{C}$. It was used for testing the inhibitory activity tests.

\section{Preparation of garlic lobes extracts}

a) Aqueous Extraction: Ten Gram of dried and crushed garlic lobes were soaked in $100 \mathrm{ml}$ of distilled water for $6 \mathrm{~h}$. at $50{ }^{\circ} \mathrm{C}$. Every two hour it was filtered through eight layered muslin cloth and centrifuged at $9000 \mathrm{rpm}$ for $10 \mathrm{~min}$. The supernatant was collected and concentrated by evaporating at $40{ }^{\circ} \mathrm{C}$ to the final volume. Strilization of aquoues extracts was carried out by filtration then, stored at $4^{\circ} \mathrm{C}$ in air tight bottles for further studies. (Parekh et al 2005). b) Solvent extraction: Ten grams of dried and crushed garlic lobes was added to $100 \mathrm{ml}$ of methanol $90 \%(\mathrm{v} / \mathrm{v})$ then, kept on a rotatory shaker 120 rpm/24.C (Lab-Line Orbital Shaker- USA Lab Equipment) for $24 \mathrm{~h}$. Thereafter, it was filtered through eight layered Muslin cloth followed by filtration using Whatman No. 1 filter paper and centrifuged at $9000 \mathrm{rpm}$ for $10 \mathrm{~min}$. the supernatant was collected and concentrated by evaporating at 40 ${ }^{\circ} \mathrm{C}$ to the final volume (10\%). The extraction was stored at $4{ }^{\circ} \mathrm{C}$ in air tight bottles till demand, as recommended by Parekh et al (2005).

\section{c) Essential oils of garlic}

The garlic essential oil was prepared by extraction of aromatic oil unit in National Research Center (NRC).

\section{Standard inoculum}

Standard inoculum was prepared by picking up 3-5 single colonies then inoculated into $5 \mathrm{ml}$ (saline solution), incubated at $37^{\circ} \mathrm{C}$ for $24 \mathrm{~h}$. After that, Optical density (O.D.) of grown culture was adjusted on spectrophotometer at $625 \mathrm{~nm}$ for reading $0.06-0.8$ which is equivalent to $\left(14 \times 10^{6} \mathrm{CFU} / \mathrm{ml}\right)$.

\section{Inhibitory effect of Allium sativum against Enterobacter sp. using well diffusion method}

Antibacterial activity of garlic extracts was tested separately using well diffusion method as described by (NCCLS, 1993). Muller Hinton agar medium was poured into petri-dishes and inoculated with $1 \mathrm{ml}$ of Enterobacter sp $\left(14 \times 10^{6} \mathrm{CFU} / \mathrm{ml}\right)$. Agar wells were made using a $7 \mathrm{~mm}$ corkborer. Each well was filled by $100 \mu$ of the tested garlic essential oil. Inoculated plates were incubated at $37^{\circ} \mathrm{C}$ for $24 \mathrm{~h}$. All experiments were carried out in triplicate and the inhibitory activity was expressed as inhibition zone diameter's mean (NCCLS, 1993).

Effect of different concentration of garlic essential oil against Enterobacter sp. by well diffusion method

Serial concentrations of garlic oil were prepared by emulsifying (30- $40-50-60-70-80$ $\% \mathrm{v} / \mathrm{v})$ in $2 \%$ of tween 80 . these concentrations of garlic oil were tested for their inhibitory activity against Enterobacter sp. Inoculum was prepared by growing Enterobacter sp. in nutrient broth for 24 
h. at $37^{\circ} \mathrm{C}$. Muller Hinton agar medium (APHA, 1992) was poured into petri-dishes. Poured dishes were inoculated with $1 \mathrm{ml}$ of Enterobacter $s p$ $\left(14 \times 10^{6} \mathrm{CFU} / \mathrm{ml}\right)$ Agar wells were made using a 7 $\mathrm{mm}$ corkborer. Each well was filled by $100 \mu \mathrm{l}$ of the tested concentrations separately. All inoculated Petri-dishes were incubated at $37^{\circ} \mathrm{C}$ for $24 \mathrm{~h}$. All experiments were carried out in triplicate and the inhibitory activity was expressed as inhibition zone diameter's mean. (Mahdi et al 2013).

GC-MS analysis of garlic essential oil: A Hewlett Packard Gas Chromatographer (HP6890) with controlled electronic pressure was used for Gas Chromatography (GC) analysis. This apparatus system is equipped with an HP-5MS (30 m x 0.25 $\mathrm{mm}$, film thickness $0.1 \mu \mathrm{m}$ ) capillary column. A detector was set at temperature range from $50{ }^{\circ} \mathrm{C}$ for 5 minutes to $280^{\circ} \mathrm{C}$. as over temperature increasing was programmed at $40^{\circ} \mathrm{C} / 5$ minutes and held for 5 minutes. $50^{\circ} \mathrm{C}$ each minute using a $\mathrm{H} 2 /$ Air mixture and split - split less injector set at $280^{\circ} \mathrm{C}$.A sample of $1 \mu \mathrm{l}$ was injected by split mode. Nitrogen gas was used as a carrier gas with a flow rate of $1.5 \mathrm{~m} / \mathrm{mm}^{-1}$. The essential oil compounds were done according to their retention indices identified by reference to a homologus series of (C4-C28) as described by (Adams, 2017).

Identification of pathogenic waterborne isolates by MALDI-TOF MS

MALDI-TOF-MS was used to analzye bacterial species as follows: single colony of a pure culture was transferred directly directly using wood backs on MALDI target plate at room temperature untill drying and over laid after over laying of samples , $1 \mu \mathrm{l}$ Bruker HCCA solution was added to all samples then allow the samples to dry. After that measure of MALDI-TOF-MS was carried out as illustrated by (Bruker, 2014).

\section{Statistical analysis}

Determination coefficient $\left(R^{2}\right)$ was calculate according to (Microsoft office Excel 2007 package)

\section{RESULTS AND DISCUSSION}

\section{Isolation and identification of Enterobacter iso- lates by MALDI-TOF MS}

MacConkey agar was used to isolate Enterobacter isolates from River Nile (Giza) in Egypt, which represent $49 \%$ of the bacterial water borne microorganisms. Medium was inoculated with $1 \mathrm{ml}$ of water sample then incubated at $37^{\circ} \mathrm{C}$ for $24 \mathrm{~h}$. Single colonies with lactose-fermenting appearance (pink and mucoid colonies) were picked up and subcultured into nutrient agar. Table (1) shows that the two isolates has a high score ranged from 2.17 and 2.32 identified as Enterobacter cloacae 3264 \& 11506, respectively.

Table 1. MALDI-TOF-MS identification of the waterborne pathogenic isolates

\begin{tabular}{|c|c|c|c|}
\hline $\begin{array}{c}\text { Isolation } \\
\text { NO. }\end{array}$ & $\begin{array}{l}\text { Isolate } \\
\text { source }\end{array}$ & $\begin{array}{l}\text { Score } \\
\text { value }\end{array}$ & $\begin{array}{l}\text { Suggest } \\
\text { strains }\end{array}$ \\
\hline 19 & $\begin{array}{l}\text { River } \\
\text { water }\end{array}$ & 2.17 & $\begin{array}{c}\text { Enterobacter cloacae DSM } \\
3264 \text { BRB }\end{array}$ \\
\hline 37 & $\begin{array}{l}\text { River } \\
\text { water }\end{array}$ & 2.32 & $\begin{array}{c}\text { Enterobacter cloacae } \\
\text { MB11506 1 CHB }\end{array}$ \\
\hline
\end{tabular}

Inhibitory effect of Allium sativum against both strains of $E$. cloacae

Different extracts of garlic were prepared using aqueous, methanolic and oil extraction methods. These extractions were tested for their inhibitory activity against Enterobacter strains using well diffusion method. Fig. (1) shows that E. cloacae DSM 3264 BRB was highly sensitive towards oil extract with inhibition zone $2.3 \mathrm{~cm}$ and $E$. cloacae $M B 115061 C H B 1.9 \mathrm{~cm}$ rather than aqueous and methanolic oil extraction. 


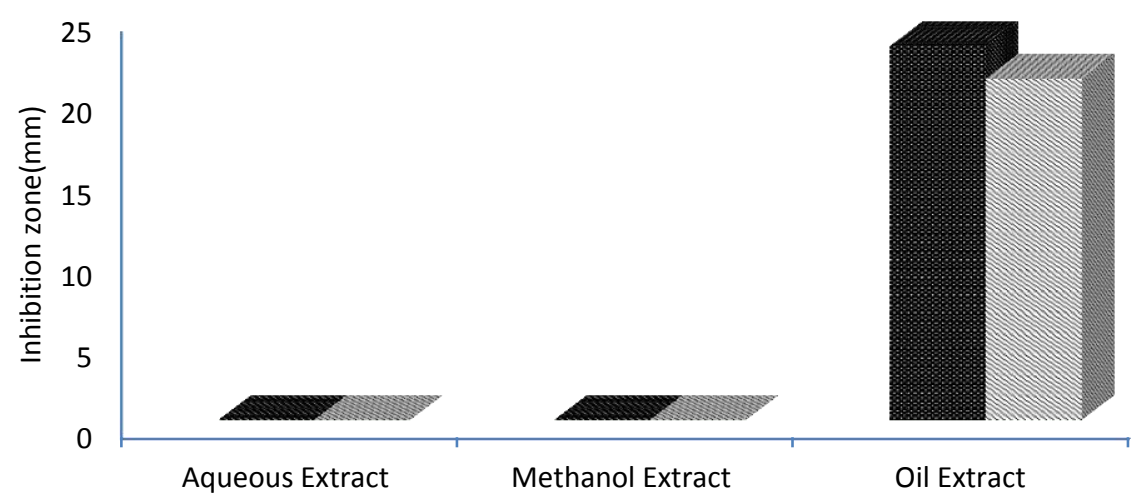

Gralic Extractions

Fig. 1. Antimicrobial activity of different garlic extracts against Enterobacter cloacae $3264 \& 11506$ strains

Effect of different concentration of garlic essential oil against Enterobacter cloacae 3264 \& 11506

Different concentrations of garlic oil extracts were prepared from $30-80 \%(\mathrm{v} / \mathrm{v})$ and tested against Enterobacter cloacae 3264\&11506 Fig. (2) shows that oil concentration $80 \%$ had the highest inhibitory activity followed by $70 \%$ and $60 \%$, respectively. These results referred to the presence of Allicin which exhibits different antimicrobial activity in the high concentration as reported by Ankri and Mirelman (1999). Determination coefficient $\left(R^{2}\right.$ of 0.94$)$ confirmed that the oil extract affected the growth significantly. These results were in agreement with previous work of garlic essential oil against Staphylococcus aureus found by (Asmaa et al 2017). Also, Goncagul, (2010) and Brij et al (2016), who stated that Allium sativum showed weaker antimicrobial activity against Gram negative bacteria than tested Gram positive bacteria.

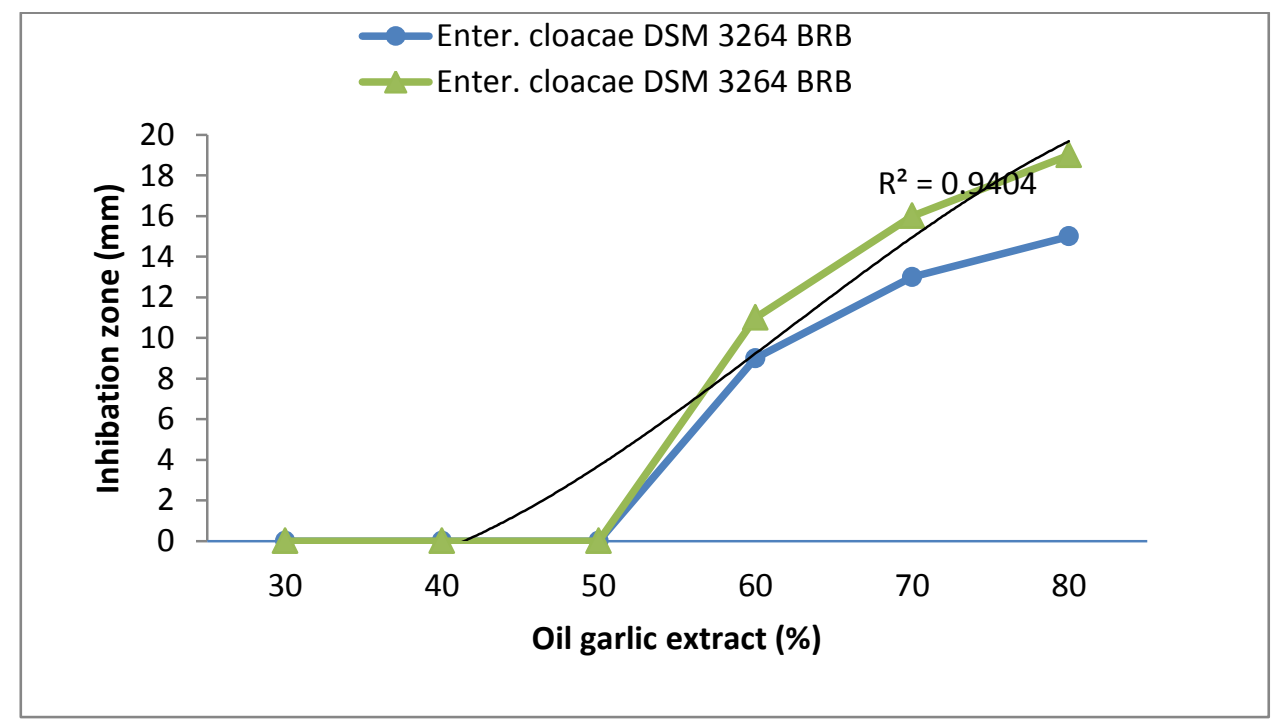

Fig. 2. Effect of oil garlic extract concentrations on Enterobacter cloacae 3264 \& 11506 strains 
Chemical constituent of garlic essential oil extract

Chemical composition of garlic oil was illustrated using GC mass technique. Table (2) shows the G.C report that identifies the chemical composition of Allium sativum. Allium sativum is chemically composed of diallyl disulphide $28.17 \%$, Trisulfide, di-2-propenyl 27.12\%, 3-(Methylthio) penta-2, 4dione $12.9 \%$ and Diallyl sulfide $9.5 \%$. These results were in similarly with Dima et al (2014) who found that diallyl disulfide components have the highest percentage in the all Allium sativum composition.

Table 2. Chemical constituents (\%) of garlic oil detected by GC-MS

\begin{tabular}{|c|c|c|c|}
\hline & Retention & $\%$ & Compound name \\
\hline 1 & 4.9377 & 9.5559 & Diallyl sulfide \\
\hline 2 & 7.0441 & 28.1784 & Diallyl disulphide \\
\hline 3 & 8.5238 & 27.128 & Trisulfide, di-2-propenyl \\
\hline 4 & 8.6434 & 0.3752 & $\begin{array}{l}\text { (Z)-1-Allyl-3-(prop-1-en-1-yl) } \\
\text { trisulfane }\end{array}$ \\
\hline 5 & 9.8387 & 12.9281 & 3-(Methylthio)penta-2,4-dione \\
\hline 6 & 11.0918 & 3.2227 & $\begin{array}{l}\text { 1-Allyl-3-(2- } \\
\text { (allylthio)propyl)trisulfane }\end{array}$ \\
\hline
\end{tabular}

\section{CONCLUSION}

The inhibitory activity of different garlic extracts show a high sensitivity on Enterobacter sp. isolated from river nile where oil extract has the most inhibitory effect followed by water and methanol extractions.

\section{ACKNOWLEDGEMNT}

The authors would like to thank Prof. Dr. Rawia Gamal, emirtus professor of microbiology for her supporting to accom- plish of this work.

\section{REFERENCES}

Adams R.P. 2017. Identification of essential oil components by gas chromatography/mass spectrometry, $5^{\text {th }}$ Ed. Carol Stream, IL: Allured Publ. Corp, pp. 2-7.

Ankri, S. and Mirelman D. 1999. Antimicrobial properties of allicin from garlic. Microbes and Infection 1, 125-129.
APHA 1992. American Public Health Association. Standard methods for the examination of water and waste waters $18^{\text {th }}$ ed. Washington, DC, USA., pp. 518-523.

Asmaa F.H., Rawia F. Gamal, Abdullaa AbdelMohsen A. and Farid A.A. 2017. Effect of addition of some plant extracts to antibiotics on pathogenic staphylococcus aureus. J. Agric. Sci., 25(2), 7-15.

Brij M.S., Rajoriya C.M., Dar-Azaz A., Rawat R.S. and Jat D.L. 2016. To study the antimicrobial properties of garlic against gram positive \&gram negative bacteria. World $\mathbf{J}$. of Pharmaceutical Research, 6(1), 772-787.

Bruker D. 2014. GmbH, Bruker Matrix, HCCA, Portioned Revision 2, pp. 2-7, www. bruker. Com/care.

Cellini L., Campli E. Di., Masulli M., Bartolomeo S.Di. and Allocati N. 1996. Inhibition of Helicobacter pylori by garlic extract (Allium sativum). FEMS Immunol Med Microbiol; 13, 273-277.

Dima M., Fabiano-Tixier A., Petitcolas E., Hamieh T., Nehme N., Ferrant C., Fernandez $X$. and Chemat F. 2014. Chemical Composition, Antibacterial and Antioxidant Activities of Six Essentials Oils from the Alliaceae Family, J. Molecules, 19, 20034-20053.

Gebreselema G. and Gebreyohannes M. 2013. Medicinal values of garlic, Int. J. Med. Medical Sci. 5(9), 401-408.

Goncagul G. 2010. Antimicrobial effect of garlic(Allium sativum). Recent Pat. Antiinfect Drug Discov., 5(1), 91-103.

Jaber M.A. and Al-Mossawi A. 2007. Susceptibility of some multiple resistant bacteria to garlic extracts. Afr. J. Biotechnol. 6(6), 771-776.

Jan Borlinghaus; Albrecht F., Gruhlke Martin C.H., Nwachukwu Ifeanyi D. and Slusarenko Alan J. 2014. Allicin: Chemistry and Biological Properties. J. Molecules. 19(8), 12591-12618.

Mahdi Khodaei Motlagh, Mohammad Y., Mohammad R. and Mansour G. 2013. Study on antibacterial effect of thyme and peppermint aqueous extracts on Staphylococcus aureus and Escherichia coli strains causing mastitis in Camels. International $\mathbf{J}$. of Traditional and Herbal Medicine. 1(4), 112-115.

NCCLS 1993. National Committee for Clinical Laboratory Standards Performance Standards for Antimicrobial Disc Suspectibility Tests. $5^{\text {th }}$ ed. Approved Standard NCCLS Publication M2-A5, Villanova, PA, USA, pp. 6-11. 
Palani S., Joseph Nisha M., Tegene Y. and Anish Z. 2014. Medicinal Properties of Garlic - A Concise Review", Current Research in Pharmaceutical Sci., 4(4), 92-98.

Parekh J., Jadeja D. and Chanda S. 2005. Efficacy of Aqueous and Methanol Extracts of Some Medicinal plants for potential Antibacterial Activity. Turk J. Bio., 29, 203-210.
Rubin D., Rajendra S. and Rawat D.S. 2012. Antibacterial effect of plants extracts on human microbial pathogens \& microbial limit test. IJRPC, 2(4), 2231-2781.

Timbo B.B., M.P. Ross; P.V. and McCarthy Lin C.T. 2006. Dietary supplements in a national survey: Prevalence of use and reports of adverse events. Am. Diet Assoc. 106(12), 19661974. 
مجلة اتحاد الجامعات العربية للطوم الزراعية ، جامعة عين شمس ، القاهرة ، مصر مجلد(26)، عدد(2D)، عدد خاص ، 2531-2525، 2019

Website: http://strategy-plan.asu.edu.eg/AUJASCl/

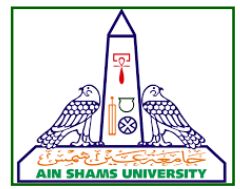

2531

\section{تأثير الثوم Allium sativium على الأنتيروياكتر كبكتريا مرضيه تنتقل عن طريق المياه ومعزوله من نهر النيل}

[186]

رشا عبد الله إبراهيم1،"- راوية فتحى جمال2 - سماح هاشم السيد محمد2 - رأفت زاهر عبد الرحمن3 3

1- المعامل المركزيه للتحاليل الطبيه وبنك الدم بالقوات المسلحة - الخليفه المأمون - القاهرة - مصر الئه 2- قسم الميكروبيولوجيا الزراعية- كلية الزراعة - جامعة عين شم - ص.ب 68 - حدائق شبرا 11241- القاهرة -

3- قسم الميكروبيولوجيا الطبية - الأكاديمية الطبية العسكرية - الخليفة المأمون - القاهرة - مصر

${ }^{*}$ Corresponding author: Eman_es2007@yahoo.com

Received 2 August, 2018, Accepted 29 August, 2018

BRB \& Enterobacter cloacae MB11506_1 CHB بقر 2.3 , 1.9 سم، بينما أعطت

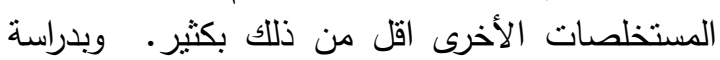
ستة نركيزات مختلفة من زيت الثوم والتى تراوحت

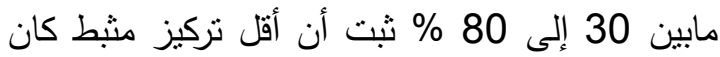

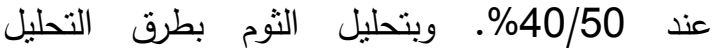

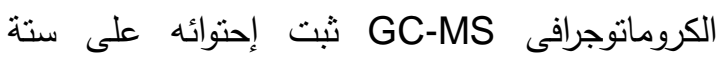
مركبات كبريتيه تمثل 25\% من المركبات الكلية (24 فئي

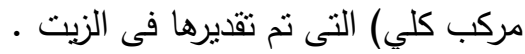

الكلمات الدالة: Enterobacter cloacae، زيت MALDI-Tof-MS, GC-MS spectrometry الثوم Allium sativum,

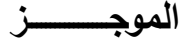

تم إستخدام الثوم بهدف إعاقة إزدياد أعداد البكتريا

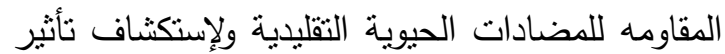
الثوم المضاد لبكتريا الإنتيروباكتر المسببه للامراض ولاضن

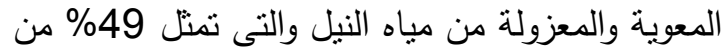

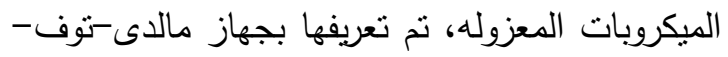
وأظهرت النتائج أنها تتبع Enterobacter cloacae DSM 3264 BRB \& Enterobacter

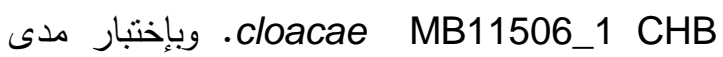
كفاءة المستخلص المائى والميثانولى وزيت الثوم على

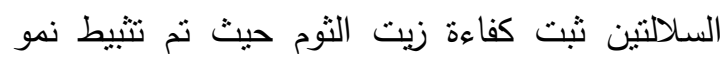
Enterobacter cloacae DSM 3264 السلالتنين 